\title{
Gross NEgLIGENCE IN CANADIAN ENERGY CONTRACTS
}

\author{
Miles Pittman, JACLyn Hesje, \\ AND ADAM LAMOUREUX ${ }^{*}$
}

The narrow definition of gross negligence in the 2007 Canadian Association of Petroleum Landmen Operating Procedure highlights the varied definitions across oil and gas contracts of gross negligence. The jurisprudence with respect to gross negligence does not follow particular patterns, and focuses instead on each case's specific facts; this has, in the author's view, led contract drafters over time to specify in detail what is and is not gross negligence. The article provides a framework for analyzing situations where gross negligence may have occurred and provides contract drafting suggestions in respect of gross negligence.
Une définition étroite de négligence grave dans l'édition de 2007 de la Canadian Association of Petroleum Landmen Operating Procedure souligne les diverses définitions de négligence grave dans les contrats pétroliers et gaziers. La jurisprudence en ce qui concerne la négligence grave ne suit pas de modèle précis et cible plutôt les faits particuliers à chaque cause. Selon l'auteur, cette situation amena les rédacteurs des contrats au fil du temps à préciser ce qui constituait une négligence grave et ce qui n'en constituait pas. L'article fournit un cadre pour analyser les situations où il peut y avoir eu négligence grave et donne des suggestions en la matière aux rédacteurs de contrat.

\section{TABLE OF CONTENTS}

I. INTRODUCTION . . . . . . . . . . . . . . . . . . . . . . . . . . . 283

II. DEFINITIONS OF GROSS NEGLIGENCE . . . . . . . . . . . . . . . . . . 285

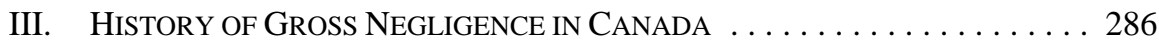

IV. RELATED TERMS . . . . . . . . . . . . . . . . . . . . . . . . . . . . 288

A. Wilful MisCONDUCT . . . . . . . . . . . . . . . . . . . . . 288

B. WANTON DiSREgARD OR MisCONDUCT $\ldots \ldots \ldots \ldots \ldots \ldots . \ldots . \ldots 289$

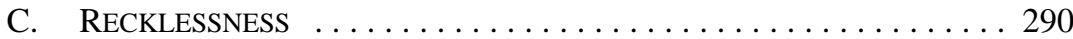

V. GRoss Negligence AND ENERgy CONTRACTS . . . . . . . . . . . . . . . . . 292

A. THE Role of the Operator . . . . . . . . . . . . . . . . . . 292

B. The Evolution of Gross Negligence IN OIL AND GAS INDUSTRY AgREEMENTS . . . . . . . . . . . . . . . 293

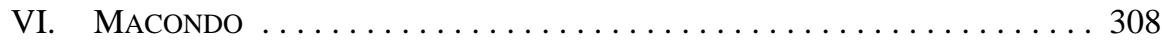

VII. CONCLUSION AND DRAFTING SUGGESTIONS . . . . . . . . . . . . . 309

\section{INTRODUCTION}

The genesis of this article is twofold.

First, as pointed out by Douglas G. Mills, Carolyn A. Wright, and Julie J.M. Inch, ${ }^{1}$ the Canadian Association of Petroleum Landmen (CAPL) CAPL 2007 Operating Procedure ${ }^{2}$

All of Norton Rose Fulbright Canada LLP, Calgary. The authors would like to thank Angela Clark and Amy Binder for their invaluable assistance in preparing this article.

Douglas G Mills, Carolyn A Wright \& Julie JM Inch, "Exploring the Balance of Power in the Operator/Non-Operator Relationship Under the CAPL Operating Procedure” (2010) 48:2 Alta L Rev 363.

2 Canadian Association of Petroleum Landmen (CAPL), 2007 CAPL Operating Procedure (Calgary: Canadian Association of Petroleum Landmen, 2007), online: CAPL <http://www.landmen.ca/pdf/ operating_procedures/2007/final/2007\%20Operating\%20Procedure\%20Text\%20(Final\%20Annotate d\%20Version\%202008).pdf> [2007 CAPL]. 
changed the scope of the operator's liability from the 1990 version. $^{3}$ It expanded the scope of matters for which the operator was entirely liable (as opposed to those matters for which the non-operators and the operator share liability pro rata in accordance with their working interest); and second, and more importantly for this article, the 2007 CAPL includes a specific definition of gross negligence. ${ }^{4}$ For certain of the operator's functions, the nonoperators must show that the operator was grossly negligent before it will be entirely liable for damages; otherwise, each of the parties must share liability pro rata. ${ }^{5}$ The definition of gross negligence in the 2007 CAPL has the effect of requiring the non-operators to show that the operator committed wilful misconduct or acted with reckless disregard or wanton indifference. This article will show that this gross negligence standard as defined may be a very high bar for the non-operators to clear to show that the operator was grossly negligent.

Second, two recent cases, Adeco Exploration Company Ltd. v. Hunt Oil Company of Canada, Inc. ${ }^{6}$ and Trident Exploration Corp. (Re), ${ }^{7}$ have highlighted the material difference between the types of operations conducted by operators in the field and those "operations" undertaken in land and contract administration. Under the rubric of the 1990 CAPL, each of the working interest owners must bear its pro rata share of liabilities unless the operator is grossly negligent, and this is irrespective of whether the operation conducted by the operator relates to the field or to contract administration. ${ }^{8}$ In each of Adeco and Trident, the Court found that the operator was grossly negligent in its conduct of administrative responsibilities.

In our view, these two cases should have sent a chilly wind through land departments everywhere. Subsequent to these cases being issued, we have had several discussions with business and legal representatives in energy related enterprises, and the question "what does gross negligence actually mean?” is one of the most frequently asked questions by their clients, and one for which there is not a straight or cogent answer. "It means whatever you want it to mean” is not a response that many clients find useful, notwithstanding that it may be the most correct response. Especially in light of the decisions in Adeco and Trident, many of these representations feel as though gross negligence, as found in these cases at least, occurs as a matter of course in industry. Moreover, what is and is not gross negligence is difficult to determine, unless contractually defined, and even then courts can use an admittedly blurry standard to remedy perceived inequitable results.

This article provides a framework for analyzing situations involving gross negligence. We will look at industry contracts and the relevant case law, both in Canada and elsewhere. Finally, in light of the historical and jurisprudential background, we will provide drafting examples and operational guidance, so that parties can prepare themselves for unforeseen situations. The endgame is providing more certainty with respect to results. In light of the cases referred to above, however, and in the absence of clearer drafting, there is now more uncertainty with respect to gross negligence, not less.

3 CAPL, 1990 CAPL Operating Procedure (Calgary, Canadian Association of Petroleum Landmen, 1990) [1990 CAPL].

2007 CAPL, supra note 2, art 1.01.

Ibid, art 4.02.

2008 ABCA 214, 437 AR 33 [Adeco].

2012 ABQB 242, 65 Alta LR (5th) 166 [Trident].

1990 CAPL, supra note 3, art 401-402. 


\section{DEFINITIONS OF GROSS NEGLIGENCE}

Simple negligence directs that a defendant must engage the degree of care expected of a reasonable person, similarly situated; ${ }^{9}$ a finding of negligence results in the weighing of the risk of and gravity of injury to the defendant against the costs incurred by a plaintiff to remediate or eliminate the risk. ${ }^{10}$ Given the inherent flexibility built into the doctrine of negligence, as Lewis Klar has noted, it is curious that the doctrine of gross negligence was developed at all. ${ }^{11}$

However, over time, legislators and contract draftspeople developed a shorthand for the most egregious forms of negligence that fell short of being wilful and could be distinguished from an intentional tort.

Black's Law Dictionary defines gross negligence as follows:

1. A lack of slight diligence or care. 2. A conscious, voluntary act or omission in reckless disregard of a legal duty and of the consequences to another party, who may typically recover exemplary damages. ${ }^{12}$

In Canada, the Dictionary of Canadian Law defines gross negligence by drawing from judicial consideration of the doctrine. ${ }^{13}$ First from Walker v. Coates:

1. Conduct in which if there is not conscious wrongdoing, there is a very marked departure from the standards by which responsible and competent people in charge of motor cars habitually govern themselves. $^{14}$

Next from Holland v. Toronto (City of) as follows:

2. The circumstances giving rise to the duty to remove a dangerous condition, including notice, actual or imputable, of its existence, and the extent of the risk which it creates - the character and the duration of the neglect to fulfil that duty, including comparative ease or difficulty of discharging it - these elements must vary in infinite degree; and they seem to be important if not vital, factors in determining whether the fault (if any) attributable to the municipal corporation is so much more than merely ordinary neglect that it should be held to be very great, or gross negligence. ${ }^{15}$

And finally from British Columbia Telephone Co. v. Quality Industries Ltd., “A high or serious degree of negligence." 16

Flowing from these are two distinct definitional streams. The first defines gross negligence in relation to simple negligence such as: "a lack of slight diligence or care"; "much more than merely ordinary neglect”; or a "serious degree of negligence.” Like ordinary negligence,

Lewis N Klar, Tort Law, 4th ed (Toronto: Thomson Carswell, 2008) at 361.

Ibid.

For more discussion on this issue refer to ibid at 362.

Black's Law Dictionary, 9th ed, sub verbo "gross negligence” [Black's].

The Dictionary of Canadian Law, 3d ed, sub verbo "gross negligence."

Ibid, citing [1968] SCR 599 at 601 [emphasis in original].

Ibid, citing [1927] 1 DLR 99 at 102 [Holland].

Ibid, citing (1984), 59 BCLR 68 (BCCA) at 71. 
gross negligence is based on an act or omission and does not incorporate a mental element. It requires a court to look at the behaviour of the defendant and apply a negligence test: it combines the "reasonable person" test set out above with a refinement reducing the standard of behaviour further — the "marked departure from the standard of behaviour" drawn from McCulloch v. Murray ${ }^{17}$ is a common test.

The second stream contemplates an act of negligence in combination with "wanton" or "reckless" disregard. Introducing the requirement of recklessness adds a mental element to gross negligence. It requires a court to infer a state of mind onto the party committing the negligence. Measuring the standard of behaviour is not enough; the plaintiff must also show that the tortfeasor was, at a minimum, "consciously indifferent," or reckless.

The second stream requires a higher threshold of proof than the first. In order to show reckless disregard, the plaintiff must either show evidence that the defendant was reckless, or infer recklessness from the defendant's actions. However, courts have often described the two varieties of gross negligence interchangeably, making it increasingly difficult to predict when gross negligence will be found. In Adeco, for instance, the Court stated that gross negligence amounts to "very great negligence,"18 “conscious wrongdoing,"19 and "“a very marked departure' from the standard of care required." ${ }^{20}$ The evolution of gross negligence over time provides some illustration of why courts now seem to use different ideas synonymously.

\section{History of Gross NegLigenCE IN CANADA}

Gross negligence was introduced in Canada by statute in an effort to limit the liability of those unjustly exposed — for example, drivers of gratuitous passengers, first responders, and municipalities performing essential services. ${ }^{21}$ However, gross negligence came without a statutory definition, leaving interpretation of the term to the courts.

The first meaningful discussion of gross negligence was in Kingston v. Drennan, ${ }^{22}$ which involved a City of Kingston bylaw requiring that every public road, street, bridge, and highway be kept in good repair. The bylaw further limited the City's liability to persons falling owing to snow or ice on sidewalks to those damages caused by the City's gross negligence. A woman who slipped climbing over a snow bank onto the sidewalk was severely injured and brought an action against the City. The Court noted that, in the past, judges went so far as to say there are no degrees of negligence (that is, they did not distinguish gross negligence from simple negligence), but concluded that it needed to give gross negligence some meaning to give expression to the legislature's intent. ${ }^{23}$ What resulted was the first Canadian definition of gross negligence: "very great negligence.”24

McCulloch v Murray, [1942] SCR 141 at 145 [Murray].

Supra note 6 at para 55.

Ibid.

Ibid.

GHL Fridman, The Law of Torts in Canada, 2d ed (Toronto: Carswell, 2002) at 402.

Kingston (City of) v Drennan, [1897] 27 SCR 46 at 60 [Kingston].

Ibid.

Ibid at 60 . 
The Supreme Court of Canada also weighed in on gross negligence in Holland. ${ }^{25}$ This case again dealt with legislation governing snow removal which exonerated the City of Toronto from liability for injuries caused by slippery sidewalks, except in the case of the City's gross negligence. ${ }^{26}$ Chief Justice Anglin for the Court noted two important factors in deciding whether the wrongful act was due to gross negligence or ordinary negligence: (1) knowledge of the risk; and (2) the length of time the risk of damages occurring is negligently left unanswered. ${ }^{27}$

The principle of gross negligence really began to take shape in response to gratuitous passenger provisions in automobile legislation. Legislatures initially sought to fully indemnify drivers from any right of action at all by guest passengers. ${ }^{28}$ Over time, the guest passenger's right of action was limited to driver conduct amounting to gross negligence or wilful and wanton misconduct. ${ }^{29}$ The leading Supreme Court of Canada case is Murray ${ }^{30}$ which dealt with the construction and application of section 183 of Nova Scotia's Motor Vehicle Act, ${ }^{31}$ affecting drivers' indemnity. Chief Justice Duff for the Court provided the following, which has found its way into nearly all subsequent gross negligence cases:

All these phrases, gross negligence, wilful misconduct, wanton misconduct [in the Motor Vehicle Act, s. 183], imply conduct in which, if there is not conscious wrong doing, there is a very marked departure from the standards by which responsible and competent people in charge of motor cars govern themselves. [S] ubject to that, ... it is entirely a question of fact for the jury whether conduct falls within the category of gross negligence, or wilful misconduct, or wanton misconduct. These words, after all, are very plain English words, not difficult of application by a jury whose minds are not confused by too much verbal analysis. ${ }^{32}$

It is clear from the case law that gross negligence continues to be decided on the facts of each case. ${ }^{33}$ Moreover, the common law structure of determining whether gross negligence exists has not changed significantly since the 1940s. The "very marked departure” language from Murray shows up in contractual definitions today - the only question for a court would be the standard from which there was a very marked departure.

In these cases, we see a contrast being drawn among gross negligence, recklessness, wanton misconduct, and wilful misconduct. Gross negligence does not require that the state of mind of the defendant be shown (only that it was grossly negligent), that the injury was reasonably foreseeable, and that the behaviour is a "very marked departure from the standards which responsible and competent people ... govern themselves." 34 This is an objective test. Each of recklessness, wanton misconduct, and wilful misconduct requires that the plaintiff show that, at a minimum, the defendant had actual knowledge of the risk of harm and was wilfully blind to the consequences.

Holland, supra note 15.

Ibid.

Ibid at 102

John Singleton, “Gross Negligence and the Guest Passenger” (1973) 11:1 Alta L Rev 165 at 165.

Ibid.

Murray, supra note 17.

SNS 1932, с 6.

Murray, supra note 17 at 145 [emphasis added].

Crinson v Toronto (City of), 2010 ONCA 44, 100 OR (3d) 366 at para 46.

Murray, supra note 17 at 145 . 
Nevertheless, in recent years courts have blurred the distinction among each of these constructs; each case must be decided on its own facts. Therefore, in order to find gross negligence, these constructs can become conflated. Broadly speaking, however, while at common law these elements do not need to be shown in order to prove gross negligence, if there is evidence of recklessness, as an example, gross negligence becomes much easier for the plaintiff to prove. In our view, if a party is reckless or exhibits wanton disregard, by definition gross negligence is likely to have occurred, regardless of the damages or the ease with which the damages could have been avoided. However, without evidence of recklessness, other factors become much more important in the determination of gross negligence - the amount of the damages, the results of non-compliance, and the relative ease of avoiding the damages in the first place. As we will show later, contractual drafting is heading towards requiring recklessness be shown before gross negligence can be shown, which will make it much more difficult to prove gross negligence. In some energy contracts, this has the effect of putting much more pressure on the non-operators to look after their own interests actively.

\section{RELATED TERMS}

Gross negligence has three legal constructs related to it, each of which imposes a mental element:

- $\quad$ wilful misconduct;

- $\quad$ wanton disregard; and

- recklessness.

The law with respect to each of these constructs is summarized below, to show overlap with, and distinguishing factors from, gross negligence.

\section{A. Wilful Misconduct}

Wilful misconduct is commonly associated with gross negligence because in many agreements, including the 2007 CAPL and the Association of International Petroleum Negotiators (AIPN) International Operating Agreement (JOA) 2012, the terms are used interchangeably. ${ }^{35}$ In the AIPN's 2002 version, the definition is of "Gross Negligence / Wilful Misconduct."36

Early case law from the Supreme Court of Canada defined wilful misconduct as "misconduct to which the will is a party. Something opposed to accident or negligence; the misconduct not the conduct must be wilful."37 Black's Law Dictionary defines it as

36 AIPN, International Operating Agreement (JOA) 2002 (Houston: AIPN, 2002) Joint Operating Agreement (2002) [2002 AIPN].

37 Lewis v Great Western Railway Co, (1878) LR 3 QBD 195 (NSCA) at 206. 
"misconduct committed voluntarily and intentionally." ${ }^{38}$ In the context of American law, Toby Hewitt notes that wilful misconduct can be distinguished from mere accident and goes far beyond negligence, even gross negligence. ${ }^{39}$ Hewitt also notes that a person's knowledge and appreciation that his or her behaviour is "wrong conduct" meets the threshold. ${ }^{40}$

Similar to gross negligence, wilful misconduct has mainly been applied in motor vehicle cases. In Murray, however, the two concepts were distinguished from each other by Chief Justice Duff:

I am, myself, unable to agree with the view that you may not have a case in which the jury could properly find the defendant guilty of gross negligence while refusing to find him guilty of wilful or wanton misconduct. $^{41}$

He went on to say that although the phrases were not equivalent, they were similar. ${ }^{42}$

Thus it appears the elements of wilful misconduct are: (1) misconduct; (2) committed voluntarily; and (3) committed intentionally. However, recent agreements, such as the 2007 $C A P L$ and the 2012 AIPN, have given gross negligence and wilful misconduct the same contractual effect, and this may have had the consequence of conflating the two concepts.

\section{B. WANTON DISREGARD OR MISCONDUCT}

"Wanton" has been used in the definition of gross negligence in the 2007 CAPL, the AIPN model agreements and the Petroleum Joint Venture Association (PVJA) model agreements. ${ }^{43}$ Wanton is also one of the terms used in the Murray decision to distinguish gross negligence. $^{44}$

According to Black's Law Dictionary, "wanton” is “[u]nreasonably or maliciously risking harm while being utterly indifferent to the consequences." 45 "Wanton misconduct" is "[a]n act, or failure to act when there is a duty to do so, in reckless disregard of another's rights, coupled with the knowledge that injury will probably result." 46

There is also "wanton disregard.” In R. v. Tutton, Justice Wilson gave a short description of the Court's view on wanton disregard while distinguishing it from gross negligence:

In short, the phrase "wanton or reckless disregard for the lives or safety of other persons" signifies more than gross negligence in the objective sense. It requires some degree of awareness or advertence to the threat to

Black's, supra note 13, sub verbo "wilful misconduct."

Toby Hewitt, "Who is to Blame? Allocating Liability in Upstream Project Contracts" (2008) 26:2 Journal of Energy \& Natural Resources Law 177 at 201.

Ibid.

Murray, supra note 17 at 145 .

Ibid.

See e.g. 2007 CAPL, supra note 2; 2012 AIPN, supra note 35; 2002 AIPN, supra note 36.

Murray, supra note 17.

Black's, supra note 13, sub verbo "wanton."

Ibid, sub verbo "wanton misconduct." 
the lives or safety of others or alternatively a wilful blindness to that threat which is culpable in light of the gravity of the risk that is prohibited. ${ }^{47}$

The finding in Tutton was in relation to section 202(1) of the Criminal Code dealing with criminal negligence. ${ }^{48}$ In that section, criminal negligence is where a person, in doing anything or omitting to do anything, shows wanton or reckless disregard for the lives or safety of others. Although the phrase wanton disregard was briefly mentioned in Murray, its relevance is more appropriate in the context of the above section of the Criminal Code and in section 163 of the Income Tax Act. ${ }^{49}$

\section{RECKLESSNESS}

Gross negligence is also regularly identified with recklessness. The Ontario Superior Court, in Machias v. Mr. Submarine Ltd. set out the elements of recklessness: (1) the creation of an obvious serious risk; and (2) such creation without consideration for the risk or, where the risk is considered, taking the risk anyway. ${ }^{50}$

Black's Law Dictionary defines the term as:

Conduct whereby the actor does not desire harmful consequence but nonetheless foresees the possibility and consciously takes the risk. [It] involves a greater degree of fault than negligence but a lesser degree of fault than intentional wrongdoing. ${ }^{51}$

Like gross negligence, recklessness appears to be something greater than negligence and less than intentional wrongdoing. Reckless disregard involves "conscious indifference to the consequences of an act." 52

Given these definitions, it is easy to confuse recklessness with wanton behaviour. The distinction can be described as follows: a party who is acting recklessly is fully aware of the unreasonable risk he or she is creating, but he or she may still be attempting to avoid harm. Someone acting wantonly may be creating the same risk of harm, but he or she is not trying to avoid the risk of harm and is indifferent to whether harm results or not. In a sense, wanton conduct can be described as "reckless plus." 53 However, this distinction illustrates the difficulty of both terms being used interchangeably to describe gross negligence and also how courts and contract drafters may use these concepts interchangeably. Our suggestion to contract drafters its to distinguish among gross negligence, wanton behaviour, reckless behaviour, and wilful misconduct wherever possible.

[1989] 1 SCR 1392 at 1407.

RSC 1985, c C-46.

RSC, 1985, с 1 (5th Supp).

2002, 24 BLR (3d) 228. See also Black's, supra note 13, sub verbo “recklessness" for a similar definition.

Black's, ibid, sub verbo "reckless."

Black's, ibid, sub verbo "reckless disregard."

Rollin M Perkins \& Ronald N Boyce, Criminal Law, 3d ed (Mineola, NY: Foundation Press, 1982) at 879-80. 
To summarize differences among the terms above:

\begin{tabular}{|c|c|c|}
\hline Terminology & Elements & Notes \\
\hline Wilful misconduct & $\begin{array}{l}\text { (1) Misconduct; (2) committed } \\
\text { voluntarily and intentionally. }\end{array}$ & $\begin{array}{l}\text { Intentionally committing a } \\
\text { wrongful act. }\end{array}$ \\
\hline Wanton & $\begin{array}{l}\text { (1) Unreasonably or maliciously } \\
\text { risking harm; (2) indifferent to } \\
\text { the consequences. }\end{array}$ & $\begin{array}{l}\text { Indifferent to a risk of harm } \\
\text { being committed. }\end{array}$ \\
\hline Wanton misconduct & $\begin{array}{l}\text { (1) Act or failure to act when } \\
\text { there is a duty to do so; (2) } \\
\text { reckless disregard of another's } \\
\text { rights; and (3) knowledge that } \\
\text { injury will likely occur. }\end{array}$ & $\begin{array}{l}\text { Knowing of the risk of harm but } \\
\text { not caring how it will effect } \\
\text { others. }\end{array}$ \\
\hline Wanton disregard & $\begin{array}{l}\text { (1) A threat to the lives or safety } \\
\text { of others; (2)(a) some degree of } \\
\text { awareness or advertence to the } \\
\text { threat; or (b) wilful blindness to } \\
\text { that threat, culpable in light of } \\
\text { the degree of risk. }\end{array}$ & $\begin{array}{l}\text { Either knowing of the risk of } \\
\text { harm or being wilfully blind to it. }\end{array}$ \\
\hline Recklessness & $\begin{array}{l}\text { (1) Creating an obvious and } \\
\text { serious risk; (2)(a) doing so } \\
\text { without giving any thought to the } \\
\text { possibility of there being any } \\
\text { such risk; or (b) having } \\
\text { recognized that there was risk } \\
\text { involved, nevertheless deciding } \\
\text { to take the risk. }\end{array}$ & $\begin{array}{l}\text { Creating the risk and doing so } \\
\text { without caring about the risk or } \\
\text { knowing about the risk and doing } \\
\text { it anyway. }\end{array}$ \\
\hline Reckless disregard & $\begin{array}{l}\text { (1) A threat to the lives or safety } \\
\text { of others; (2) some degree of } \\
\text { awareness or advertence to the } \\
\text { threat; or (3) wilful blindness to } \\
\text { that threat, culpable in light of } \\
\text { the degree of risk. }\end{array}$ & $\begin{array}{l}\text { Either knowing of the risk of } \\
\text { harm or being wilfully blind to it. }\end{array}$ \\
\hline
\end{tabular}

The chart above illustrates the differences among the concepts but also how they are different from "very great negligence.” Using any of these terms, the plaintiff must show the defendant's state of mind. 


\section{Gross NegLigenCE AND ENERgy CoNTRACTS}

\section{A. THE ROLE OF THE OPERATOR}

In the development of joint lands, joint owners elect an operator among themselves. Accordingly, the operator wears two hats: joint owner and independent contractor for the rest of the joint owners (in otherwords, the non-operators). ${ }^{54}$ Clause 3.03A of the 2007 CAPL defines the operator's role as follows:

\footnotetext{
The Operator is an independent contractor in activities hereunder. It will supply or cause to be supplied all material, labour and services reasonably necessary for [the operations authorized and conducted for the joint account which means the sharing of benefits, risks, costs, expenses and obligations ("Joint Operations”)]. It will determine the number of employees and contractors required for Joint Operations, their selection, their hours of labour and their compensation, and they will be regarded as the Operator's employees and contractors. The Operator's status as an independent contractor does not alter its responsibility for liability and indemnification, which will continued to be governed by [the liability and indemnity provisions] of this Agreement. $^{55}$
}

Therefore, while contractual fault is usually apportioned between contracting parties based on their failure to perform, the operator's standard of performance is limited by contract. The role of the operator carries with it significant risk and little financial reward (although there are clear planning and process advantages in being operator). In order to allocate this risk more fairly, the industry devised a regime where all matters relating to the joint operations were borne by the joint account. Each of the operator and non-operators are responsible to the joint account in an amount proportionate to their respective working interest. This is so even though the operator alone is responsible for conducting joint operations. The only exception is where the costs arise as a result of the operator's gross negligence or wilful misconduct, in which case the operator alone bears the costs.

Over time, as Mills, Wright, and Inch have shown, ${ }^{56}$ the operator's contractually required standard of performance diminished under the 1990 CAPL and increased under the 2007 $C A P L$, in that there are several basic operating duties, where, if breached, the operator is liable for simple breach of contract. However, for those items where the operator is liable only for its own gross negligence (which are the major operator's duties under the 2007 $C A P L$ ), the operator's standard of performance has decreased, due to the addition of a new definition of gross negligence. In our view, the 2007 CAPL sets an extremely high, and potentially impossibly high, bar for the non-operators to clear before they can impose liability on the operator for the operator's gross negligence. 


\section{B. THE EVOLUTION OF GROSS NEGLIGENCE IN OIL AND GAS INDUSTRY AgREEMENTS}

Instances in which the gross negligence test has been analyzed by the courts have predominately involved head office matters - accounting, allocation, and land, not major operational or wellsite damage. Considering how gross negligence provisions are worded in industry agreements, it is worth asking whether the gross negligence standard was ever intended to address head office matters at all or was instead intended to protect the operator from claims for its own negligence with respect to operational or wellsite matters. Wellsite matters are perhaps more appropriately indemnified because: (1) they carry the greatest risk for the operator; and (2) operational damage is usually covered by insurance carried on by the joint account or by the non-operators separately. A cursory survey of upstream energy producers reveals that internal accounting and land mistakes are not covered by insurance.

As a result of case law, along with the stated desire of the CAPL drafting committee to bring the gross negligence standard in the 2007 CAPL more in line with AIPN standards, ${ }^{57}$ the standard for gross negligence as set forth in the 2007 CAPL is markedly different from the 1981 version or the 1990 CAPL, where gross negligence was undefined. ${ }^{58}$ In the 2007 $C A P L$, for example, accounting mistakes are clearly excluded from the gross negligence standard but land and maintenance of title documents are clearly included.

1. Gross Negligence in CAPL Operating Procedures AND “NON-CAPL” OPERATING AGREEMENTS

a. 1981 CAPL Operating Procedures and Non-CAPL Operating Agreements

i. $\quad$ United Canso Oil \& Gas Ltd. v. Washoe Northern Inc. ${ }^{59}$

The first major case involving gross negligence in the oilpatch and its effect on operators' liability is United Canso.

The exclusion of operator's liability in United Canso operating agreement provided:

6. Liability

(a) Joint-Operator's right of action against Managing-Operator is strictly limited to action for loss, damage or costs caused by the gross negligence or wilful misconduct of Managing-Operator in the performance of, or in the failure to perform, Managing-Operator's obligations under this Agreement.

(b) Loss, damage or costs caused to the parties or any of them from third party claims arising out of operations for the joint account shall be borne and paid by the parties, other than Managing-Operator,

CAPL, Annotations (Calgary, Canadian Association of Petroleum Landmen, 2007), online: CAPL $<$ http://www.landman.ca/pdf/operating-procedures/2007/final/2007\%20Operating\%20Procedure\%20 Annotations\%20(Final2008).pdf>.

582007 CAPL, supra note 2; CAPL, 1981 CAPL Operating Procedure (Calgary, Canadian Association of Petroleum Landmen, 1981) [1981 CAPL]; 1990 CAPL, supra note 3.

59 (1991), 121 AR 1 (QB) [United Canso]. 
in proportion to their interests in the particular Properties involved, but Managing-Operator shall save Joint-Operators harmless from any such claims to the extent that the same are attributable to the gross negligence or wilful misconduct of Managing-Operator. ${ }^{60}$

This language suggests that a "very great negligence" or "marked departure” threshold ${ }^{61}$ would be the appropriate test — gross negligence was undefined in the contract.

United Canso involved a dispute among a number of producers, with Husky, Asamera, and Lasmer operating over time, and United Canso being one of the non-operators. United Canso was the successor to three carried interests and party to the governing Joint Operating Agreement. United Canso had been under-allocated proceeds of production due to a myriad of accounting errors by the various operators, who were successors as operator under the Joint Operating Agreement. United Canso argued that the failure to keep proper accounts was a breach so egregious that it amounted to gross negligence. United Canso had to bring its claim under the Joint Operating Agreement, rather than in unjust enrichment, because other parties who had been over-allocated proceeds no longer had the funds to repay United Canso. Accordingly, the equities of repayment rested with United Canso; it was owed the money, and the operators argued that they were required to meet a gross negligence standard only in the allocation of production proceeds (that is, each did not have to allocate correctly, or even negligently, but grossly negligently before it was responsible). Otherwise, each of the parties to the Joint Operating Agreement would have to pay its pro rata share of the underallocated amounts to United Canso.

Justice Hutchinson found that the constituting agreements had not been properly interpreted, which resulted in a failure to follow the correct accounting procedure. ${ }^{62} \mathrm{He}$ found, however, that clause 6(a) above limited the operators' liability to situations in which it was grossly negligent, regardless of the activity being performed (including allocating production in accordance with the accounting procedure). ${ }^{63}$

The Court explored an array of definitions of "gross negligence," as they had been applied in the oil and gas industry, relying largely on American jurisprudence, and noted that most Texas courts favoured the interpretation of "gross negligence" offered by Judge Stayton in Missouri Pacific Ry. Co. v Shudford:

Gross negligence, to be the ground for exemplary damages, should be that entire want of care which would raise the belief that the act or omission complained of was the result of a conscious indifference to the rights or welfare of the person or persons to be affected by it.... Gross negligence is positive or affirmative, rather than merely passive or negative as ordinary negligence often, and perhaps usually, is. ${ }^{64}$

This phrase clearly contemplates that a mental element would need to be proved by the plaintiff before gross negligence would be found. The use of the words "conscious indifference" is a strong indicator that the plaintiff would need to show actual evidence of 
the recklessness of the defendant. Justice Hutchinson also adopted the analysis used in Murray, below, and suggested that showing that either the defendant was reckless, or exhibited a "marked departure from the standard of behaviour" would have been sufficient to show gross negligence. ${ }^{65}$

The Court found that Husky was partially protected from liability. The Court did not accept that a number of small errors over 13 years could be described as "conscious wrongdoing" or a "very marked departure" from the standard of care required ${ }^{66}$ However, between February 1981 to when Husky turned over responsibilities of Managing Operator to Asamera, one of the other parties in 1982, Husky's failure to account to United Canso constituted gross negligence or wilful misconduct. The reason was that one of the beneficiaries of the overpayment was a related Husky entity ${ }^{67}$ There is an implication in the case that Husky owed a higher duty of care (and therefore the threshold establishing gross negligence was lower) where one of its related parties benefitted.

It is not clear, but the Court implies that it was easier to find conscious indifference where a Husky related party stood to gain. The findings with respect to Husky starkly illustrate the importance of the equities in each of these cases. While Husky's actions may have been no different before and after a Husky entity was the payee of the overpayment, the Court found that it had been grossly negligent. As a practical matter, courts likely find gross negligence easier to award when there is a sense that one of the parties is unduly benefiting.

The Court found that Asamera and Lasmer as operators had the responsibility to interpret the constituting agreements correctly and to allocate the proceeds received properly. The Court found the following factors were of assistance when determining whether these defendants crossed the threshold from negligent to grossly negligent:

- $\quad$ full disclosure of the accounting and interpretation problems was made to Asamera and Lasmer at the time they acquired their interests and they "must have realized that there was a real risk that they were paying monies to the other Joint Operators which might properly have belonged to the plaintiff;";8

- $\quad$ “Asamera attempted to resolve the problems which it inherited from the Husky defendants through a series of meetings," 69 but there was no final result and both Asamera and Lasmer "simply continued on recording revenues, expenses and capital expenditures”; ${ }^{70}$

- “neither Asamera nor Lasmer sought advice and directions elsewhere"; ${ }^{71}$ and

Murray, supra note 17 at 145.

United Canso, supra note 59 at para 345.

Ibid.

Ibid at para 341.

Ibid at para 342 .

Ibid.

Ibid. 
- $\quad$ "the outstanding issues were either ignored or else a calculated risk was taken by Husky the accounting was correct or that the plaintiff would not pursue the issues."72

The Court found that these failures amounted to gross negligence, as they exhibited a "very marked departure from the standards by which reasonable and competent companies in a like position to that of Asamera and Lasmer ... should habitually govern themselves."73 The Court went on to suggest what would have prevented such a finding of gross negligence, and stated that an operator's proper recourse was to seek advice and directions from the Court concerning the accounting issues. ${ }^{74}$

The result in United Canso appears to have had the effect of starting the industry down the road to contractually limiting the gross negligence standard. In many other circumstances, what would conventionally be thought of as negligence or simple breach of contract was viewed as gross negligence as a result of the way the contract was drafted in order to give the aggrieved parties a remedy. In the abstract, it does not appear that any of the operators, but specifically Asamera and Lasmer, were grossly negligent. However, it appeared to be unacceptable to the court to limit the recovery of non-operators to gross negligence, as such drafting allows the operator to commit manifest error. This decision shows how the courts were (and are) unwilling to allow manifest errors, and if gross negligence is the way they have to do it, so be it.

\section{ii. The 1981 CAPL Operating Procedure: Erehwon Exploration Limited v. Northstar Energy Corporation ${ }^{75}$}

The first case dealing with the issue of gross negligence under CAPL, with perhaps unexpected results as a result of expansive contractual interpretation, is Erehwon. In Erehwon, Northstar made a number of accounting errors and levied inappropriate charges in its capacity as operator under a 1981 CAPL and relied on United Canso to show that, provided the language is specific enough, a gross negligence standard would be upheld. This argument was categorically rejected by Justice Hunt, as she then was.

First, Justice Hunt compared the exclusion language in United Canso to the 1981 CAPL. In United Canso, the joint-operator's right of action was "strictly limited to action for loss, damage or costs caused by the gross negligence of the Operator."76 The 1981 CAPL does not limit a right of action. Instead it states:

The Operator shall not be liable to the Joint Operators for any loss or damage incurred by any of them relative to any operations carried out pursuant to this Operating Procedure except that ... the Operator shall be solely liable for any loss or damage of whatsoever nature when such loss or damage is caused by the

Ibid.

Ibid.

Ibid at para 346.

(1993), 147 AR 1 [Erehwon].

United Canso, supra note 59 at para 320. 
Operator's gross negligence or wilful misconduct but no act or omission of the Operator, its agents or employees. $^{77}$

It is a very fine legal distinction between limiting the right of action for loss arising from the operator's gross negligence (as in United Canso) and limiting liability for loss or damage to that caused by the operator's gross negligence (as in Erehwon). Nevertheless, on that basis, Justice Hunt distinguished United Canso. She went on to find that it was extremely improbable that the intent of the drafters was that all liability for all operations to be conducted by the operator were to be shared by the parties in accordance with their pro rata share, except where the operator was grossly negligent. She states:

[I]t is hard to imagine that the parties could have intended Art IV to mean that the Operator could then carry out its accounting obligations in a grossly negligent fashion. That they would agree, by contract, to stand behind the Operator for uninsured third party losses arising from actions that are "negligent” as opposed to "grossly negligent” is more understandable.

\begin{abstract}
Many operations carried out under CAPL are high-risk and the Non-Operators may be willing to accept that, as a "first among equals" acting on behalf of co-venturers, it would be expecting too much for the Operator to have responsibility for losses caused by its negligence .... it is understandable that the parties have accepted the gross negligent standard in relation to third party losses and have, in effect, agreed to pay their share of losses resulting from the Operator's negligence.
\end{abstract}

I do not see this reasoning applying to the accounting relations between the parties, however. It would give the Operator much greater power to act as it wishes vis a vis the Non-Operators than seems to me consistent with a reasonable commercial interpretation of CAPL. Potentially, it would give the Operator a sort of tyrannical role in relations to Non-Operators. I do not believe that this was the intention of the parties. ${ }^{78}$

In fact, while Justice Hunt found that it was extremely improbable that this could have been the intent of the parties, it was likely the intent of the CAPL drafting committee. Northstar put forth evidence from the CAPL drafting committee as evidence of the intent that gross negligence had to be shown in all cases before the operator would be found to bear more than its pro rata share of liability. However, Justice Hunt was concerned that the gross negligence standard was being imposed inappropriately on operator's covenants. In our view, the words of the $1981 C A P L$ were clear — a gross negligence standard was the appropriate standard. Nevertheless it stands to reason that accounting matters should be held to a different standard from actions on a wellsite, and this seems to be the Court's view as well.

Justice Hunt's sensible, if expansive, interpretation of the CAPL led to changes in the 1990 CAPL, and more recently in the 2007 CAPL, in which accounting mistakes are not held to a gross negligence standard. However, the 2007 CAPL drafting committee saw fit to hold "maintenance of title documents" to the gross negligence standard. ${ }^{79}$ It is this standard that many non-operators have found troubling. Under the Western Canadian land system, the 
Operator is responsible for submitting renewals, for paying royalties, and for generally maintaining crown leases; it is the only party vis-à-vis the Crown who can do so. However, the non-operators must show that the operator is grossly negligent before it can bear more than its working interest share of liability.

\section{b. 1990 CAPL Operating Procedure}

As a result of Justice Hunt's decision in Erehwon, the CAPL adopted very strict limitation of operator liability language in the 1990 CAPL, which holds an operator liable for loss only where the act or omission constitutes gross negligence or wilful misconduct and was not in accordance with instructions from the joint operators. The relevant clause is set out below:

\section{ARTICLE IV}

INDEMNITY AND LIABILIY OF OPERATOR

401 — LIMIT OF LEGAL RESPONSIBILITY — Notwithstanding Clauses 303 and 304, the Operator, its Affiliates, directors, officers, servants, consultants, agents and employees shall not be liable to the other Joint-Operators, or any of them, for any loss, expense, injury, death or damage, whether contractual or tortious, suffered or incurred by the Joint-Operators resulting from or in any way attributable to or arising out of any act or omission, whether negligent or otherwise, of the Operator or its Affiliates, directors, officers, servants, consultants, agents, contractors or employees in conducting or carrying out joint operations, except:

(b) when and to the extent that such loss, expense, injury, death or damage is a direct result of, or is directly attributable to, the gross negligence or willful misconduct of the Operator or its Affiliates, directors, officers, servants, consultants, agents, contractors or employees, provided that an act or omission of the Operator or its Affiliates, directors, officers, servants, consultants, agents, contractors or employees shall be deemed not to be gross negligence or willful misconduct, insofar as such act or omission was done or was omitted to be done in accordance with the instructions of or with the concurrence of the Joint-Operators. ${ }^{80}$

The proviso at the beginning of the clause is a specific reference to the obligation that the operator has to operate in accordance with good oilfield practice and as an independent contractor. Therefore, notwithstanding the operator's covenant to operate in accordance with good oilfield practice, it is never liable for more than its pro rata share except when it is grossly negligent and the matter is done of its own accord. It would be difficult for Justice Hunt to arrive at the same conclusion she did in Erehwon under the 1990 CAPL, given the revised language. In our view, accounting mistakes (and perhaps more significantly, land mistakes) would be held to a gross negligence standard — as they were in Adeco. 
i. $\quad$ Adeco Exploration Company Ltd.

v. Hunt Oil Company of Canada, Inc.

The conclusion that land mistakes would be held to a gross negligence standard, but that standard would be malleable, was borne out in Adeco. Hunt Oil Co. (Hunt Oil), Adeco Exploration Company Ltd. (Adeco), and Shaman Energy Corporation (Shaman) were parties to a joint operating agreement which incorporated the terms of the 1990 CAPL. Hunt Oil was designated operator, and two leases that expired in May 2001 were included in the Joint Operating Agreement.

A month before expiry, Hunt Oil's landperson sought and obtained the consent of Adeco and Shaman to have the leases continued. On the day of expiry, the continuation applications were submitted, and they included well logs and production data. On 3 August 2001, the Crown wrote to Hunt Oil and stated that only a portion of each lease would be continued, unless "additional evidence of productivity" was submitted to support the application within one month of 3 August (Hunt Oil received the letter on 22 August 2001). Hunt Oil did not submit any further information, and the contested portions expired. It was subsequently determined that it would have been very easy to have the leases continued.

There were some clear mistakes made at Hunt Oil. The landperson in charge of the parcels said that it was her practice to consult with technical personnel to see if anything else could be submitted and was informed that Hunt Oil would have to let the leases expire. It became clear that the technical information was simply wrong.

There was some question at trial as to whether Hunt Oil provided notice of the application to Adeco and Shaman, but it seems accepted by the court at trial that each of Adeco and Shaman did receive copies of both the continuation application and the 3 August letter from the Crown prior to the expiry date of 3 September and did not follow up with Hunt Oil. They assumed that Hunt Oil, as a good operator, would have completed and submitted the revised continuation application.

Justice Ritter for the Alberta Court of Appeal interpreted the 1990 CAPL as the drafters likely intended — that the standard of performance that the operator is held to is anything short of gross negligence, irrespective of what the operator's obligations are:

\footnotetext{
This language [in Section 401] is clear and unambiguous.... Here, what Hunt Oil failed to do in continuing the lease, constitutes an omission in conjunction with Hunt Oil carrying out the joint operation. Pursuant to the plain and ordinary meaning of the words in clause 401 of the 1990 CAPL, Hunt Oil is only responsible to the non-operators, Adeco and Shaman, if its omission amounted to gross negligence. ${ }^{81}$
}

Relying on this language, the Court found Hunt Oil to have been grossly negligent in the performance of its duties as operator by failing to continue the leases. In doing so, in our view, the Court of Appeal significantly lowered the threshold for what acts or omissions constitute gross negligence - land mistakes, if they were easy to rectify or easy to avoid, could be held tantamount to gross negligence, and the operator would be held liable. 
Justice Ritter examined a number of definitions of gross negligence:

- "very great negligence";82

- “conscious wrongdoing” or a "very marked departure" from the standard of care required; ${ }^{83}$ and

- "the character and the duration of the neglect to fulfil [the] duty, including the comparative ease or difficulty of discharging it [are] important, if not vital, factors in determining whether the fault (if any) ... is so much more than merely ordinary neglect that it should be held to be a very great, or gross negligence," and "conscious indifference." 84

Justice Ritter did not distinguish between "very great negligence" and "conscious indifference.” Instead, he conducted a hindsight examination of what Hunt could, or should, have done differently, and Hunt's failure to do so constituted gross negligence. He characterized the Hunt system for continuing leases as "dreadfully deficient" — one which should have treated continuation applications with more care. He compared the Hunt land system to a law office where an unknowing person is responsible for limitation periods, and then checks with a similarly uninformed person. He stated that he would have no hesitation in determining that the firm in question was grossly negligent.

The factors used by the Court in determining whether gross negligence existed were:

- although a letter was received from Alberta Energy pointing out the deficient applications, Hunt Oil did not contact Alberta Energy to request additional time; ${ }^{85}$

- Hunt Oil did not inquire why there had been a significant delay between when the deficiency notice was sent and when it was received; ${ }^{86}$ and

- Hunt Oil's technical personnel was wrong in determining that the leases should be continued. $^{87}$

From the outside, it appears that the Hunt Oil system is not that different from every other oil company in Western Canada. A land administrator and landperson are in charge of continuations; they ask a technical person if lands are worth continuing, and they respond appropriately. These companies are under pressure to reduce overhead and accordingly land departments become overburdened. Somewhere along the way the system breaks down likely in communication between the land person and the technical person. It is difficult to see how this is gross negligence - it is a mistake or a series of mishaps. If anything, it is negligence, but surely not gross negligence. Otherwise many other land departments are

Ibid at para 55, citing Kingston, supra note 22 at 60.

Ibid, citing Murray, supra note 17 at 42.

Ibid, citing Holland, supra note 15 at 634.

Ibid at para 51 .

Ibid.

Ibid at para 53. 
grossly negligent as a matter of course. The test is "markedly different from the standard of behaviour required.”

It is also worth considering why Adeco and Shaman were not required to mitigate their damages. They had notice of the request to Hunt Oil to submit further information and did not follow up with Hunt Oil to ensure the information was sent. The trial judge found that "it was not unreasonable for Adeco and Shaman to assume that Hunt Oil, as a good operator, would do what the operating agreement required it to do," ${ }^{88}$ and therefore Adeco and Shaman were not contributorily negligent. However, as Justice Ritter pointed out, the test for Hunt Oil was gross negligence - an admittedly very low standard. In the case where gross negligence is the standard, one wonders if it is not the responsibility of the non-operators to mitigate their damages - in this case, by following up with Hunt Oil and ensuring that the application went in on time. The incorrect assumption from Adeco and Shaman contributed to the leases being lost.

Nevertheless, failing to impose a gross negligence standard on Hunt Oil in this case would have the effect of unfairly depriving Adeco and Shaman of their rights under the leases, where they relied on Hunt Oil to perform its obligations. Here is perhaps the greatest problem with the use of the gross negligence standard in "operations.” In an operator or non-operator environment, non-operators are reliant on the operator to perform its duties. In return, the operator gets to set the agenda for operations under the relevant agreement. It needs to protect itself against claims by third parties, or claims where damages are easily recompensable by insurance. Hence, the use of the "gross negligence" threshold. However, the use of the gross negligence threshold throughout the 1990 CAPL had unforeseen consequences. It is difficult to see the reasoning for not excluding maintenance of title documents and other land administration matters from the gross negligence standard. In return for the increased responsibility, the operator could charge a larger operating fee.

\section{ii. $\quad$ Trident Exploration Corp. $(\mathrm{Re})$}

The next case involving gross negligence is once again a land case. Trident Exploration Corp. (Trident), Bearspaw Petroleum Ltd. (Bearspaw), Mutiny Oil \& Gas Ltd. (Mutiny), and F.M. Kaplan Technical Services Ltd. (Kaplan) were parties to a Pooling Agreement dated 12 April 2005. Trident was appointed operator of the lands, and the 1990 CAPL was incorporated into the agreement. Mutiny was the beneficial owner (in trust for others as well) of the lease in the north half of the section, while Trident, Bearspaw, and Kaplan held the lease in the south half of the section.

In June 2005, Alberta Energy issued a Gas Offset Notice to Blaze, Trident, and Bearspaw (as registered owners of the leases). The notice provided that if the parties failed to respond by 7 December 2005, the lessees would be deemed to surrender the lands down to the producing section. Blaze forwarded a copy of the offset to Mutiny.

In response to the offset notice, Trident wrote a letter to Mutiny, Bearspaw, and Kaplan, drawing their attention to the offset obligation and recommending that the obligation be 
satisfied by paying the offset compensation to the Crown and that Trident would do so in its capacity as operator. The 10 November 2005 letter stated "Trident will make the payment to the Crown and invoice the partners at their pooled interest share,” and asked Mutiny, Bearspaw, and Kaplan to provide their approval or non-approval of this recommendation. ${ }^{89}$ Trident added "[a]s we wish to satisfy this obligation as soon as possible, your prompt response will be appreciated."90 Mutiny subsequently verbally agreed with this approach. Trident then received a written response to their letter from Bearspaw, who indicated that Trident should not reply to the offset notice on behalf of all parties and that Bearspaw would send its own reply.

Trident acted on Bearspaw's letter but failed to notify Mutiny of the change in plans. The next time this matter came to the attention of Mutiny was the following spring when Mutiny discovered through public documents that it no longer had rights to the lands and that the lands had been posted by Bearspaw. Mutiny sued Trident, claiming that Trident was grossly negligent in failing to submit the information with respect to the offset to the Crown.

\section{Justice Kent found Trident grossly negligent:}

\footnotetext{
What Trident did was not a momentary lapse. It wrote a letter that can reasonably be interpreted as meaning that Trident would respond to the offset notice on behalf of all the partners. It received word from Bearspaw that ... each partner should look after its own lease. Trident's failure to advise Mutiny that the plan had changed was something that could have been easily accomplished.... There was plenty of time for Trident to ensure that all partners understood what their obligations were, given Bearspaw's response. That is gross negligence. $^{91}$
}

In the Court's view, Trident assumed the responsibility for complying with the offset notice and then, when Bearspaw relieved Trident of its responsibility to do so with respect to the Bearspaw lease, Trident simply did not follow up with Mutiny. Clear negligence but gross negligence?

In determining what amounted to gross negligence, the Court considered the Adeco case and the various meanings of gross negligence noted there. The phrases cited in Adeco included:

- very great negligence;

- conscious wrongdoing;

- a very marked departure from the standard of care;

- the character and the duration of the neglect to fulfil [the] duty, including comparative ease or difficulty of discharging it [are] important, if not vital, factors in determining 
whether the fault (if any) ... [is] so much more than merely ordinary neglect that it should be held to be a very great, or gross negligence; and

- conscious indifference. $^{92}$

We can see that the Court in this case used what we have described as the two definitional streams of gross negligence - the "very great negligence" standard, and the "mental element” standard interchangeably. Given the Court's conclusion, and the strong language used by Justice Kent to describe Trident's omission, the mental element standard would in our view have been met; the Court would have found that Trident exhibited conscious indifference.

This case again begs the question whether Mutiny did enough to mitigate its damages. If gross negligence is the standard for maintenance of title documents, which it clearly is as a result of the Adeco decision, should Mutiny have followed up with Trident to ensure that its lease was being handled? Mutiny assumed that Trident would have done what it said it would, but if gross negligence is the standard, such assumptions seem foolhardy. ${ }^{93}$

\section{c. $\quad 2007$ CAPL Operating Procedure}

In the $2007 C A P L$, both the risk allocation provisions and the scope of gross negligence were amended significantly. First, the drafting committee included the following definition for gross negligence:

\footnotetext{
“Gross Negligence or Wilful Misconduct” means any act, omission or failure to act (whether sole, joint, or concurrent) by a person that was intended to cause, or was in reckless disregard of or wanton indifference to, the harmful consequences to the safety or property of another person or to the environment which the person acting or failing to act knew (or should have known) would result from such act, omission or failure to act. However, Gross Negligence or Wilful Misconduct does not include any act, omission or failure to act insofar as it: (i) constituted mere ordinary negligence; or (ii) was done or omitted in accordance with the express instructions or approval of all Parties, insofar as the act, omission or failure to act otherwise constituting Gross Negligence or Wilful Misconduct was inherent in those instructions or that approval. ${ }^{94}$
}

The effect of these changes is to further narrow the scope of the definition of gross negligence, such that if the non-operators wish to show that the operator has been grossly negligent and hence responsible for more than its pro rata share of liabilities, it must either show reckless disregard, wanton indifference to harmful consequences, which such party knew, or should have known would result from such act. The committee stated that it was attempting to bring the definition of gross negligence further in line with the AIPN Model

Adeco, supra note 6 at para 23.

For an excellent discussion and useful suggestions for drafting see William M Laurin, “Operator Liability for Administrative ‘Gross Negligence’” Energy Law Bulletin (18 June 2012), online: Lawson Lundell LLP <http://www.lawsonlundell.com/media/news/300_EnergyBulletinOperatorLiabilityAd ministrativeGrossNegligence.pdf $>$. 2007 CAPL, supra note 2 , art 1.01. 
Joint Operating Committee. ${ }^{95}$ However, in doing so, it has, in our view made it extremely difficult to impose liability on the operator. After Adeco, we know that the 1990 CAPL holds that the operator must be shown to be grossly negligent in all cases before being held liable for more than its pro rata share; now, under the 2007, the circumstances where the operator must be shown to be grossly negligent are fewer, but actually showing that the operator was grossly negligent is much harder.

If we unpack this definition, we see that:

(1) the non-operators must show either intent to cause harmful consequences (that is, wilful misconduct); or reckless disregard or wanton indifference to harmful consequences; and

(2) that the consequences were actually or reasonably foreseeable.

In every case, the non-operators must show evidence either directly or by inference that the operator had some advertent knowledge of the consequences and ran the risk anyway, or was wilfully blind as to the consequences. The "very great negligence" or "marked departure" stream of interpretation has been excluded from the definition. When courts are interpreting this definition, they will no longer be able to rely on the statements from the Supreme Court in Holland and Murray and instead will be required to judge the operator's state of mind.

Defining negligence in this way added some certainty to the operator's risk profile, but has in our view significantly reduced the possibility that it would be held liable for more than its pro rata share of damages. For example, based on the facts in Adeco and Trident, the courts would have found it significantly more difficult to impose liability on the operator as the "marked departure" test is no longer available under the 2007 CAPL. In Adeco, the nonoperators would have been required to show that Hunt's land system was deliberately deficient, or that Hunt had recklessly set up its system, not caring about the consequences that would result if continuations were missed. In Trident, the non-operators would have been required to show that, by failing to send Mutiny notice that it would be responsible for sending in its own offset election, it did so advertently, or in wanton indifference or reckless disregard of Mutiny's rights, rather than simply forgetting. It will not be enough to be grossly negligent; now, the non-operators will have to show that the operator knew about the consequences or were reckless about the consequences. Matters "falling through the cracks," as in both Adeco and Trident, will not meet the test, even when the cracks are a mile wide.

The decision in Adeco did have a happy consequence for operators, however: it confirmed that the standard of performance before it became liable for more than its pro rata share was gross negligence, irrespective of the contractual duty being performed. In the 2007 CAPL, there are several of the operator's duties which do not have this limitation, and accordingly the operator would be liable. ${ }^{96}$ www.landman.ca/pdf/operating_procedures/2007/final/Modifications(2)\%20to\%201990\%200per\% 20Proc\%20(June\%202007).pdf >. 
The risk allocation provisions in the 2007 CAPL are set out below:

4.00 LIABILITY AND INDEMNIFICATION OBLIGATIONS

4.01 Indemnification of Operator

This Clause applies except insofar as the Operator: (i) is solely responsible for any Losses and Liabilities under Clause 4.02; or (ii) may otherwise be liable to any Party for breach of any of its contractual obligations as Operator under this Agreement, other than for its duties under Clause 3.04, Subclause 3.05A or Subclause $3.10 A$

\subsection{Limit of Operator’s Legal Responsibility}

The Operator, its Affiliates and their respective directors, officers and employees will not be liable to any of the Non-Operators for any Losses and Liabilities resulting from or in any way attributable to or arising out of any act, omission or failure to act, whether negligent or otherwise, of the Operator or its Affiliates and their respective directors, officers, agents, contractors or employees in the performance of the Operator's duties under this Agreement (including those in planning or conducting any Joint Operation), except insofar as:

(a) those Losses and Liabilities are a direct result of, or are directly attributable to the Gross Negligence or Wilful Misconduct of the Operator, its Affiliates or their respective directors, officers, employees, agents or contractors; [or]

(b) the Operator may otherwise be liable to any Party for breach of any of its contractual obligations as Operator under this Agreement, other than for Clause 3.04, Subclause 3.05A or Subclause 3.10A. ${ }^{97}$

Hence, the operator's liability for covenants other than those contained in clauses 3.04, 3.05A, or 3.10A is not limited to the gross negligence standard. For example, Clause 3.07, requires the operator maintain "true and correct records and accounts," and if it fails to do so, it can be liable to the non-operators for the entire amount of the loss, not just its pro rata share. ${ }^{98}$ There are a number of similar obligations in the 2007 CAPL for which the operator does not have limited liability.

However, subclause 3.10A deals with the maintenance of title documents, and is thus liable for its pro rata share of liabilities arising from its failure to maintain title documents, except where it is grossly negligent (as defined). This requires that:

Except as otherwise provided in this Agreement ... the applicable Title Administrator [usually the Operator] will, on behalf of the Parties and for the Joint Account, comply with the Title Documents, including the payment of rentals and other actions required to maintain them in good standing. ${ }^{99}$ 
Therefore, non-operators will be required to show that the operator was reckless, or wantonly indifferent before being held liable for more than its pro rata share of liabilities.

In an ironic twist, in its annotation of Clause 3.10A, the CAPL drafting committee points out how important it is to establish expectations around which party was responsible for maintaining title documents, especially in a non-cross-conveyed pooling agreement. Of course, this was exactly what happened in Trident. Trident's landman assumed that Mutiny would be sending in its own offset response, while Mutiny's landman, based on communication from Trident, assumed that Trident would be.

\section{Petroleum Joint Venture Association}

The PJVA provides another set of model agreements, and has developed a more flexible definition of gross negligence, more consistent with the case law and less so with the AIPN model.

The PJVA model form Unit Operating Agreement defines “Gross Negligence” as:

a marked and flagrant departure from the standard of conduct of a reasonable Person acting in the circumstances at the time of the alleged misconduct, or such wanton and reckless conduct or omissions as constitutes in effect an utter disregard for harmful, foreseeable and avoidable consequences. ${ }^{100}$

It is clear how this definition differs from the 2007 CAPL definition of gross negligence or wilful misconduct - it includes both an objective and a subjective test, permitting the non-operators some ability to recover against the operator without having to show reckless or wanton conduct or omissions.

\section{ASSOCIATION OF INTERNATIONAL PETROLEUM NEgOtiators CONTRACTS}

As the use of models became commonplace in domestic industries, the international petroleum exploration and exploitation industry discovered a need for a similar model agreement for the industry's unique challenges. In 1990, the AIPN developed a model joint operating agreement based in large part on the American and Canadian models. ${ }^{101}$ When it came to gross negligence, the AIPN engaged the common practice in the international industry of limiting operator liability to acts or omissions of gross negligence to reflect the “no profit no loss” approach to operatorship. ${ }^{102}$

Among a host of risks arising in international petroleum projects is the tendency for operations to take place in hostile physical and geopolitical locations. ${ }^{103}$ With greater risk comes greater concern about operator liability. It is not uncommon for well qualified international operators to refuse to act as operator unless the joint operators indemnify them 
from claims arising for their own gross negligence. ${ }^{104}$ Also given the broad range of risks, the AIPN Model Contract contains more flexibility than its domestic counterparts.

The 1995, 2002, and 2012 versions all provide a definition of "gross negligence.” Between the 1995 AIPN and the 2012 AIPN, there have been no substantive changes to the definition except in the 2002 AIPN when "wilful misconduct" was added as having the same contractual effect as "gross negligence.” Article 1.01 of the 2012 AIPN (which is effectively the same as the $2002 \mathrm{AIPN}$ ) defines gross negligence/wilful misconduct as:

\footnotetext{
"Gross Negligence or Willful Misconduct” means any act or failure to act (whether sole, joint or concurrent) by any person or entity that was intended to cause, or was in reckless disregard of, or wanton indifference to, harmful consequences or ... harmful consequences to the safety or property of another person or to the environment which the person acting or failing to act knew (or should have known) would result from such act, omission or failure to act. ${ }^{105}$
}

This definition was incorporated, in large measure, into the 2007 CAPL. The difficulty with simply transferring the AIPN definition into the CAPL agreement is that the AIPN is a model agreement that is designed for the drafter to adapt to any number of different jurisdictions. However, it is not a definition that aligns with the common law of gross negligence, giving rise to the challenge of requiring the aggrieved party to show intent, reckless disregard, or wanton indifference.

The importance of the AIPN model contracts in the Canadian energy industry has been increasing, due to the prominence of large scale joint ventures for exploitation of upstream shale or other assets, where the CAPL Operating Procedure has proved insufficient. For instance, because the AIPN contract provides for an Operating Committee, and for Work Programs and Budgets, many upstream joint venturers, especially those with international operations or experience, have come to rely on the AIPN model as a useful starting point. Further, the AIPN model is intended as a guide and has significant imbedded flexibility, while the CAPL procedures have been drafted so that they can be used as a code for operations throughout the basin.

The standard clause in the 2012 AIPN provides that the operator is indemnified against all losses howsoever arising, including from the operator's own gross negligence. However, the option exists to require the operator to be liable for its gross negligence through the use of optional clauses. If the parties elect to adopt the optional clause and thereby attach greater risk and liability to the operator for gross negligence, there remains the further flexibility to limit that risk and liability as much or as little as desired. The AIPN model permits parties to choose from three options regarding damages that arise from gross negligence. Parties to an international JOA can elect for the operator to:

- bear all the damages arising from claims against the operator's gross negligence; 
- bear only the actual costs of repairing or replacing the joint property damaged by the operator's gross negligence; or

- bear only a defined amount of the damages arising from such a claim. ${ }^{106}$

Where anything short of all damages falling with the operator, the balance of the damages and liabilities would be split in proportionate share with the other joint operators' participating interest in the JOA. Also, in any event under the AIPN Model Contract, the operator is never responsible for anything more than its proportionate share of consequential damages and environmental losses. ${ }^{107}$

This flexibility highlights another unique quality to the AIPN model contracts: they were drafted in contemplation of use in both civil and common law jurisdictions. The AIPN Model Contract includes a warning that Article 4.6, as set out above, may not be enforceable in common law jurisdictions. ${ }^{108}$

\section{MACONDO}

Gross negligence was in the spotlight recently in Louisiana. The concept is central to the ongoing litigation surrounding the Deepwater Horizon oil spill. BP as operator of the Deepwater Horizon platform is facing a myriad of liabilities, including compensatory damages in private tort actions, civil penalties in environmental law, punitive damages awarded under federal maritime and state tort law, the comparative allocation of fault among the defendants, and, most important for present purposes, contractual indemnification obligations to co-defendants. ${ }^{109}$ Critical to determining the extent or applicability of these liabilities is the degree of negligence applied by the Court. ${ }^{110} \mathrm{~A}$ finding by the Court that BP as operator was grossly negligent will not only have an impact contractually, it may also determine liability and punitive damages under the Clean Water Act ${ }^{111}$ and Oil Pollution Act ${ }^{112}$ and impact damage awards in tort claims. ${ }^{113}$

The Macondo well was jointly owned by BP, Anadarko, and MOEX, with respective ownership shares of 65 percent, 25 percent, and 10 percent. ${ }^{114}$ Under the governing joint operating agreement, the losses are to be shared proportionately except those resulting from a party's gross negligence or wilful misconduct. ${ }^{115}$ If it is found that BP was grossly negligent under the Clean Water Act and the Oil Pollution Act, then BP will face 100 percent of the liability rather than liability being limited to its 65 percent working interest. ${ }^{116}$

Duval et al, supra note 101 at 294.

Association of International Petroleum Negotiators, Model Contracts, online: AIPN < https://www.aipn. org/mcvisitors.aspx> [AIPN Model Contract]. Ibid at iii.

Blaine LeCesne, "Crude Decisions: Re-Examining Degrees of Negligence in the Context of the BP Oil Spill” (2012) Michigan State Law Review 103 at 105.

Ibid.

33 USC § 1251 (2006).

33 USC §§ 2701-62 (2006).

LeCesne, supra note 106 at 116.

Ibid.

Ibid.

Ibid at 116. 
Furthermore, the requirement for BP to indemnify the joint owners from their liability will be triggered.

\section{CONCLUSION AND DRAFTING SUGgESTIONS}

This article has attempted to demonstrate that gross negligence is, in the absence of clear contractual drafting, an area where courts are not afraid to provide broad interpretation. The decisions in Adeco and Trident show a willingness to find the operator grossly negligent. The CAPL Drafting Committee has responded by providing a definition of gross negligence in the 2007 CAPL which does not allow a court to impose an objective test (that is, the "marked departure" test), and instead requires the non-operators to show the state of mind of the operator. This may prove to be very difficult. Also, this article has attempted to highlight a difficult proposition: that the operator can only be held liable for failure to maintain title documents where it is shown to be grossly negligent, and, even then, it must be shown to have acted recklessly or wantonly before liability more than its pro rata share would be imposed.

For the purposes of oil and gas operating agreements, there are three reasons why establishing a clear definition of gross negligence is significant:

(1) to provide clarity to the contracting parties, to avoid unpredictable outcomes;

(2) to establish the outer (or inner) boundary of where operators' liabilities are limited; and

(3) to establish the outer (or inner) boundary of where operators are indemnified for carrying out their duties under the operating agreement and for carrying out joint operations.

The difficulty with specific definitions of gross negligence is the expectations of the parties. When contracting parties say "gross negligence," do they actually mean “recklessness,” or do they mean “very great negligence or recklessness”? An informal survey of in-house counsel indicates the latter although the former may in fact be preferred. Further, even with a restrictive definition of gross negligence, there are likely situations where courts will bend over backwards to find the operator grossly negligent to remedy perceived inequities.

The obvious option available to contract draftspeople is to ignore the mandated definition and insert one in the head agreement which is more useful or more applicable to the situation. Below is an example of a recently drafted definition of gross negligence from a joint venture agreement:

Gross Negligence means a marked and flagrant departure from Good Industry Practice at the time of the alleged misconduct, or such wanton and reckless conduct or omissions as constitutes in effect an utter disregard for harmful, foreseeable and avoidable consequences. For greater certainty, Gross Negligence does not include: 
(a) an individual act or omission of an employee, agent, consultant, contractor or representative of a Person that constitutes or results from an error in judgment or an honest mistake unless such act or omission in the context of the relevant facts and circumstances amounts to conduct of the nature described above;

(b) an act or omission of ordinary negligence; or

(c) an act or omission that was done or was omitted to be done with the Approval of the Management Committee.

This definition provides both the "marked departure" (also inserting the word "flagrant," contained in the PJVA Model Contract), and a recklessness standard in the alternative; in this way, it allows the non-operators not to have to prove a mental element, but only that the acts of the operator were themselves so removed from good business practices as to warrant the operator assuming liability.

The first proviso is also interesting - it allows that the operator can make mistakes, but it does require the operator to have a system in place. Under this definition in Adeco, as an example, Adeco might have been able to avoid a finding of gross negligence because something fell through the cracks.

Other considerations that may impact the definition drafting include considerations of:

- the risk to operator or non-operators regarding factors internal to the agreement (extent of limitation of liability);

- the risk to the joint operations regarding factors external to the agreement and the level of control available to the operator to control those risks (extent of indemnification);

- the scope of the limit to liability or indemnity, this is, only the operator and its affiliates, directors and officers or employees;

- the market for operators or for experienced and qualified operators;

- the applicable law of the agreement; and

- the source of injury contemplated in the limit to liability and indemnity provisions.

Ultimately, the best approach might be grounded in other considerations that impact the relationship between the parties. In the case of limits to liability, consideration may be given to the reputation and experience of the operator, the relationship between the parties, and perhaps the overall size of the industry all impacting the comfort level of non-operators to limit the operator's liability when they suffer damages. Where the comfort level is higher, perhaps non-operators would be willing to consider only intention to cause harm rather than deferring to some industry standard which may catch an operator off guard. 
In the case of indemnification, consideration may be given to external factors, such as if the operator operating in a country with a transparent and navigable rule of law. If not, it may be unduly onerous on the operator to face potential gross negligence claims if, say, they failed to properly renew a concession they were unaware was subject to renewal due to a lack of transparency.

One thing is certain, however. Simply assuming that the gross negligence standard is the same in all agreements is an error. The inherent flexibility of the concept, combined with courts' desire to balance the equities, means that contract draftspeople should consider the circumstances before adopting a particular definition. Specifically, in our view, parties to the CAPL procedures need to be aware of the fact that the standard of performance of the operator is a very low standard. The gross negligence standard governs throughout the 1990 $C A P L$, as a result of Adeco. In the 2007 CAPL, the gross negligence standard requires the non-operators to show that the operator showed reckless disregard. Non-operators are well advised, therefore, to maintain shadow land systems, and, where the 1990 CAPL governs, shadow accounting systems.

Finally, operators should make more of the arguments around contributory negligence and mitigation in the circumstances. In each of Adeco and Trident, at least on the facts disclosed, it would have been possible for each of the non-operators to have followed up with the operator to check what was going on. Given the importance of the outcome, it would have been prudent to do so, and one therefore wonders if a court will, in a different fact scenario, impose liability on the operator, but reduce its liability because the non-operators were either contributorily negligent or failed to mitigate. 